Jurnal Jeumpa, 7 (2) Juli-Desember 2020

\title{
PEMANFAATAN BAHAN ALAMI SEBAGAI UPAYA PENGHAMBAT Candida albicans PADA RONGGA MULUT
}

\author{
Nurul Makhfirah"1, Cut Fatimatuzzahra², Vivi Mardina ${ }^{3}$, Rachmi Fanani Hakim ${ }^{4}$ \\ Program Studi Biologi, Fakultas Teknik, Universitas Samudra, Jl. Prof. Syarief Thayeb, \\ Meurandeh, Langsa, Aceh, Indonesia. 24416 \\ Departemen Oral Biologi, Fakultas Kedokteran Gigi, Universitas Syiah Kuala, Jl. Teuku Tanoh \\ Abee, Kopelma Darussalam, Syiah Kuala, Banda Aceh, Aceh, Indonesia. 24415 \\ *E-mail koresponden: vmardina@unsam.ac.id
}

\begin{abstract}
ABSTRAK
Candida albicans merupakan salah satu flora normal yang keberadaannya paling banyak terdapat pada rongga mulut, kulit, membran mukosa, saluran pencernaan, saluran pernapasan dan vagina. Penyakit yang disebabkan oleh Candida albicans yaitu penyakit kandidiasis oral (moniliasis). Penggunaan bahan obat-obatan dalam jangka waktu yang lama dapat menimbulkan resistensi fungi terhadap obat dan beberapa obat memiliki efek negatif. Oleh karena itu berbagai penelitian telah dilakukan untuk mencari alternativ lain sumber obat yang mampu menghambat pertumbuhan Candida albicans. Umumnya penelitian melaporkan bahwa senyawa-senyawa yang terkandung pada tumbuhan memiliki sifat anti-fungi terhadap Candida albicans. Senyawa/ zat aktif tersebut adalah flavonoid, tanin, saponin, alkaloid, polifenol, triterpenoid dan beberapa komponen aktif seperti alpha-mangostin.
\end{abstract}

Kata Kunci: Flora normal, Candida albicans, Kandidiasis, Antifungal, Senyawa alami

\begin{abstract}
Candida albicans is one of the normal flora whose presence is mostly found in the oral cavity, skin, mucous membranes, digestive tract, respiratory tract and vagina. The disease caused by Candida albicans is oral candidiasis (moniliasis). The use of medicinal substances for a long time can lead to fungal resistance to drugs and some drugs have negative effects. Therefore, various studies have been conducted to find alternative sources of drugs that can inhibit the growth of Candida albicans. Generally, research reports that the compounds contained in plants have anti-fungal properties against Candida albicans. The active compounds / substances are flavonoids, tannins, saponins, alkaloids, polyphenols, triterpenoids and several active components such as alpha-mangostin.
\end{abstract}

Keywords: Normal flora, Candida albicans, Candidiasis, Antifungal, Natural compounds 


\section{PENDAHULUAN}

Indonesia merupakan negara beriklim tropis dengan suhu kelembaban udara yang tinggi. Adanya kondisi udara yang lembab, maka dapat mempermudah terjangkitnya infeksi jamur pada masyarakat. Salah satu jenis jamur yang mudah menjangkit masyarakat Indonesia yaitu golongan jamur Candida albicans (Sudrajat et al., 2011).

Jamur Candida albicans adalah flora normal yang keberadaannya paling banyak pada kulit, membran mukosa, rongga mulut, saluran pencernaan, saluran pernapasan dan vagina. Pada awalnya Candida albicans bersifat non patogen, namun ketika adanya faktor predisposisi, Candida albicans akan bersifat patogen (Wjaya, 2017). Beberapa faktor predisposisi yang dapat membantu proses pertumbuhan Candida albicans seperti penggunaan antibiotik dalam jangka yang panjang, tidak terkontrolnya aktivitas diabetes melitus, pemakaian gigi palsu yang terus menerus, defisiensi zat besi, vitamin $\mathrm{B}_{12}$, asam fosfat dan kondisi imunosupresi yang buruk (Suryaningsih et al., 2015).

Secara morfologi Candida albicans berbentuk ragi, tunas, oval dan ada yang berbentuk seperti pseudohifa yang dapat menghasilkan hifa sejati (Brook, et al., 2010). Rahman dan KN (2010) menyatakan bahwa dalam rongga mulut, Candida albicans
Jurnal Jeumpa, 7 (2) Juli-Desember 2020

biasanya berjumlah kurang lebih sekitar 200 sel per mililiter saliva. Dalam keadaan seperti ini Candida albicans akan berubah menjadi penyakit kandidiasis yang disebut juga sebagai infeksi monilia. Kandidiasis oral (moniliasis) termasuk jenis infeksi pada rongga mulut manusia akibat Candida albicans. (Prasidha, 2011). Menurut Irianto (2014) 85 - 95\% infeksi kandidiasis oral akibat adanya bentuk perlekatan dari Candida albicans pada dorsum lidah, mukosa bukal, mukosa labial dan daerah sekitar palatum. Sedangkan menurut hasil penelitian Kalista (2017) data tahun 2012-2014 infeksi yang disebabkan Candida albicans memiliki tingkat mortalitas yang tinggi dengan prevalensi kandidiasis invasif sebanyak 12,3\%. Penelitian Alzaera et al., (2015) menemukan $70 \%$ dari 100 pasien penderita diabetes melitus di Saudi Arabia yang mengalami infeksi kandidiasis yang diakibatkan oleh Candida albicans. Sedangkan menurut penelitian Yusri et al., (2012) mengatakan bahwa Candidiasis vulvaginalis merupakan salah satu jenis infeksi oportunistik yang paling sering ditemukan di rumah sakit Adam Malik Medan yaitu sebanyak 109 dari 309 kasus.

Bermacam jenis obat antijamur yang telah banyak diproduksi dan dijual dipasaran untuk mengobati infeksi Candida albicans 
Jurnal Jeumpa, 7 (2) Juli-Desember 2020

(kandidiasis) yang menyerang rongga mulut. Namun, obat-obatan tersebut memilki efek samping seperti alergi, rasa mual dan beberapa kasus menimbulkan iritasi. Penggunaan dalam jangka waktu yang lama juga akan menimbulkan masalah resistensi Candida albicans terhadap obat. Oleh karena itu, diperlukannya pengobatan dengan menggunakan bahan-bahan alami yang diharapkan menimalisir efek samping atau sebagai langkah awal skrining kandidat antijamur (Deza, 2010).

\section{METODE PENELITIAN}

Metode yang digunakan dalam penulisan artikel ini adalah literature review. Literature review yaitu sebuah pencarian literatur baik internasional maupun nasional yang dilakukan dengan menggunakan database EBSCO, ScienceDirect, dan Proquest google scholar. Sementara data yang digunakan dalam penulisan artikel ini diperoleh dari penelusuran pustaka jurnal dan artikel ilmiah baik internasional maupun nasional melalui situs google scholar (https://scholar.google.co.id/) dan situs NCBI. Hasil penelitian yang dicantumkan dengan kata kunci "Flora normal, Candida albicans, Kandidiasis, antifungal dan senyawa alami". Didapat jurnal sebanyak 56 jurnal. Jurnal-jurnal tersebut kemudian diskrining dan didapat 35 jurnal nasional dan 21 jurnal internasional untuk ditinjau lebih lanjut.

\section{HASIL}

Berdasarkan hasil dari 56 jurnal yang dikumpulkan, terdapat banyak penelitian yang mennatakan bahwa penggunaan bahan alami terbukti mampu menghambat pertumbuhan Candida albicans. Adapun hasil dari jurnal yang telah didapat dapat dilihat pada tabel berikut ini.

\begin{tabular}{|c|c|c|}
\hline No & Hasil Penelitian & $\begin{array}{c}\text { Daftar } \\
\text { Pustaka }\end{array}$ \\
\hline 1 & $\begin{array}{l}\text { Secara invitro, eksrak } \\
\text { daun belimbing wuluh } \\
\text { mampu menghambat } \\
\text { pertumbuhan Candida } \\
\text { albicans pada konsentrasi } \\
20 \% \text { sampai } 80 \% \text {. }\end{array}$ & $\begin{array}{l}\text { Sari dan } \\
\text { Suryani, } \\
2014\end{array}$ \\
\hline 2. & $\begin{array}{l}\text { Ekstrak flavonoid rendah } \\
\text { nikotin limbah daun } \\
\text { tembakau } \\
\text { (Nicotiniana tabaccum } \mathrm{L} \text {.) } \\
\text { memiliki daya hambat } \\
\text { yang lemah terhadap } \\
\text { pertumbuhan jamur } \\
\text { Candida albicans. }\end{array}$ & $\begin{array}{l}\text { Fatimah, } \\
2016\end{array}$ \\
\hline 3. & $\begin{array}{l}\text { Eksrak daun sirsak } \\
\text { memiliki rerata zona } \\
\text { hambat sebesar } 12,5 \mathrm{~mm} \\
\text { sehingga dikategorikan } \\
\text { memiliki daya hambat } \\
\text { terhadap pertumbuhan } \\
\text { jamur Candida albicans. }\end{array}$ & $\begin{array}{l}\text { Masloman } \\
\text { et al.,, } \\
2016\end{array}$ \\
\hline 4. & $\begin{array}{l}\text { Ekstrak methanol daun } \\
\text { sembung rambat efektif } \\
\text { dalam menghambat } \\
\text { pertumbuhan jamur } \\
\text { Candida albicans }\end{array}$ & $\begin{array}{l}\text { Alfiah et } \\
\text { al., } 2015\end{array}$ \\
\hline
\end{tabular}


Jurnal Jeumpa, 7 (2) Juli-Desember 2020

\begin{tabular}{|c|c|c|}
\hline 5. & $\begin{array}{l}\text { ekstrak etanol daun lidah } \\
\text { buaya (Aloe vera) dapat } \\
\text { menghambat } \\
\text { Staphylococcus } \\
\text { dan jamteri } \\
\text { albicans }\end{array}$ & $\begin{array}{l}\text { Sulistyowa } \\
\text { ti, } 2012\end{array}$ \\
\hline 6. & $\begin{array}{l}\text { Eksrak daun jarak efektif } \\
\text { terhadap pertumbuhan dan } \\
\text { membunuh jamur } \\
\text { Candida albicans }\end{array}$ & $\begin{array}{l}\text { Sukmawati } \\
\text { et al., } 2017\end{array}$ \\
\hline 7. & $\begin{array}{l}\text { Pada konsentrasi paling } \\
\text { tinggi } 90 \% \text { mempunyai } \\
\text { persentase daya antifungi } \\
\text { sebesar } 22 \% \text { dibandingkan } \\
\text { ketokonazol. }\end{array}$ & $\begin{array}{l}\text { Nuryani } \\
\text { dan } \\
\text { Jhunnison, } \\
2016\end{array}$ \\
\hline 8. & $\begin{array}{l}\text { Madu huta Sulawesi } \\
\text { tengah dengan konsentras } \\
20 \%-100 \% \text { tidak dapat } \\
\text { menghambat } \\
\text { pertumbuhan Candida } \\
\text { albicans }\end{array}$ & $\begin{array}{l}\text { Pokote, } \\
2018\end{array}$ \\
\hline 9. & $\begin{array}{l}\text { Ekstrak daun lidah mertua } \\
\text { dapat menghambat } \\
\text { pertumbuhan Candida } \\
\text { albicans tetapi tidak } \\
\text { jernih. }\end{array}$ & $\begin{array}{l}\text { Komala et } \\
a l ., 2012\end{array}$ \\
\hline 10. & $\begin{array}{l}\text { Daya hambat ekstrak } \\
\text { rimpang kencur } \\
\text { (Kaempferia galangal L.) } \\
\text { terhadap pertumbuhan } \\
\text { Candida albicans terjadi } \\
\text { pada konsentrasi } 50 \\
\text { mg/ml. }\end{array}$ & $\begin{array}{l}\text { Rahmi et } \\
\text { al., } 2016\end{array}$ \\
\hline 11. & 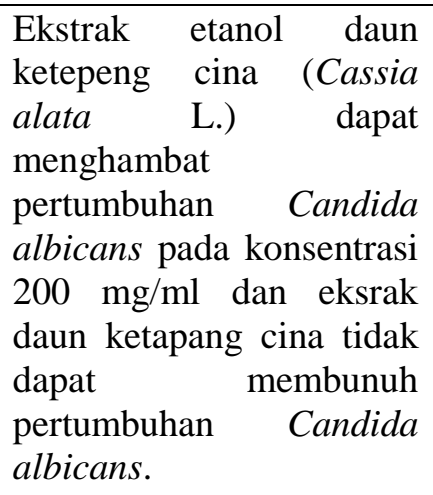 & $\begin{array}{l}\text { Gharnita et } \\
\text { al., } 2019\end{array}$ \\
\hline
\end{tabular}

\begin{tabular}{|c|c|c|}
\hline 12. & $\begin{array}{lr}\text { eksrak daun } & \text { sirih merah } \\
\text { (Piper } & \text { crocatum) } \\
\text { berpengaruh } & \text { terhadap } \\
\text { pertumbuhan } & \text { Candida } \\
\text { albicans. } & \end{array}$ & $\begin{array}{l}\text { Rezeki et } \\
\text { al., } 2017\end{array}$ \\
\hline 13. & $\begin{array}{l}\text { perasan rimpang kunyit } \\
\text { (Curcuma longa L.) } \\
\text { memiliki daya hambat } \\
\text { terhadap pertumbuhan } \\
\text { Candida albicans }\end{array}$ & $\begin{array}{l}\text { Harianto et } \\
\text { al., } 2017\end{array}$ \\
\hline 14. & $\begin{array}{l}\begin{array}{l}\text { minyak atsiri bawang } \\
\text { merah } \\
\text { ascalonicum L.) } \\
\text { (Allium } \\
\text { dengan }\end{array} \\
80 \% \text { terbukti dapat } \\
\text { menghambat } \\
\text { pertumbuhan bakteri } \\
\text { Candida albicans }\end{array}$ & $\begin{array}{l}\text { Hidayatull } \\
\text { ah, } 2012\end{array}$ \\
\hline 15. & $\begin{array}{l}\text { Ekstrak daun dewa } \\
\text { (Gynura pseudochina } \\
\text { (Lour.) DC) } 10 \% \text { dapat } \\
\text { menghambat } \\
\text { pertumbuhan Candida } \\
\text { albicans pada plat dasar } \\
\text { gigi tiruan resin akrilik. }\end{array}$ & $\begin{array}{l}\text { Rahman, } \\
2020 . .\end{array}$ \\
\hline 16. & $\begin{array}{l}\text { Air buah jeruk nipis } \\
\text { (Citrus aurantifolia) pada } \\
\text { konsentrasi 20\%, } 40 \% \text {, } \\
60 \%, 80 \% \text {, dan } 100 \% \\
\text { tidak dapat menghambat } \\
\text { jamur Candida albicans }\end{array}$ & $\begin{array}{l}\text { Maimunah } \\
, 2018\end{array}$ \\
\hline 17. & $\begin{array}{l}\text { Ekstrak bawang putih } \\
\text { dapat menghambat } \\
\text { pertumbuhan Candida } \\
\text { albicans pada bahan basis } \\
\text { gigi tiruan valplast }\end{array}$ & Sari, 2014 \\
\hline 18. & $\begin{array}{l}\text { Pada konsentrasi } 25 \% \\
\text { perasan daun turi } \\
\text { (Sesbania grandiflora }(\mathrm{L} .) \\
\text { Pers.) paling efektif untuk } \\
\text { menghambat jamur } \\
\text { Candida albicans }\end{array}$ & $\begin{array}{l}\text { Tivani dan } \\
\text { Wilda, } \\
2020\end{array}$ \\
\hline 19. & $\begin{array}{lr}\text { Ekstrak buah pinang tua } \\
\text { (Areca } & \text { catechu } \quad \text { L.) } \\
\text { memiliki } & \text { aktivitas }\end{array}$ & $\begin{array}{l}\text { Sopiah et } \\
\text { al., } 2017\end{array}$ \\
\hline
\end{tabular}


Jurnal Jeumpa, 7 (2) Juli-Desember 2020

\begin{tabular}{|c|c|c|}
\hline & $\begin{array}{l}\text { antijamur terhadap jamur } \\
\text { Candida albicans tepatnya } \\
\text { pada konsentrasi } 45 \% \\
\text { mempunyai aktivitas daya } \\
\text { hambat bagi aktivitas } \\
\text { jamur Candida albicans }\end{array}$ & \\
\hline 20. & $\begin{array}{l}\text { VCO (Virgin Coconut Oil) } \\
\text { mampu menghambat } \\
\text { pertumbuhan jamur } \\
\text { Candida albicans yang } \\
\text { diisolasi dari sampel swab } \\
\text { vagina. VCO pada } \\
\text { konsentrasi 90\% memiliki } \\
\text { daya hambat paling tinggi } \\
\text { dibandingkan dengan } \\
\text { konsentrasi lain yang } \\
\text { sebesar } 24 \text { mm }\end{array}$ & $\begin{array}{l}\text { Burhannud } \\
\text { din et al., } \\
2017\end{array}$ \\
\hline 21. & $\begin{array}{l}\text { Seduhan teh hitam tidak } \\
\text { memilki efek terhadap } \\
\text { pertumbuhan } \\
\text { albicans }\end{array}$ & $\begin{array}{l}\text { Felita et } \\
\text { al., } 2020\end{array}$ \\
\hline 22. & $\begin{array}{l}\text { Ekstrak Acanthus ilicifilus } \\
\text { pada konsentrasi } 8 \% \\
\text { efektif dalam menghambat } \\
\text { pertumbuhan Candida } \\
\text { albicans }\end{array}$ & $\begin{array}{l}\text { Andriani et } \\
\text { al., } 2017\end{array}$ \\
\hline 23. & $\begin{array}{lr}\begin{array}{l}\text { Ekstrak daun } \\
\text { hutan }\end{array} & \begin{array}{r}\text { kedondong } \\
\text { (Spondias } \\
\text { pinnata)ada } \\
\text { konsentrasi }\end{array} \\
100 \% & \text { menghambat } \\
\text { pertumbuhan } & \text { Candida } \\
\text { albicans } & \end{array}$ & $\begin{array}{l}\text { Wijayanti } \\
\text { et al., } 2020\end{array}$ \\
\hline 24. & 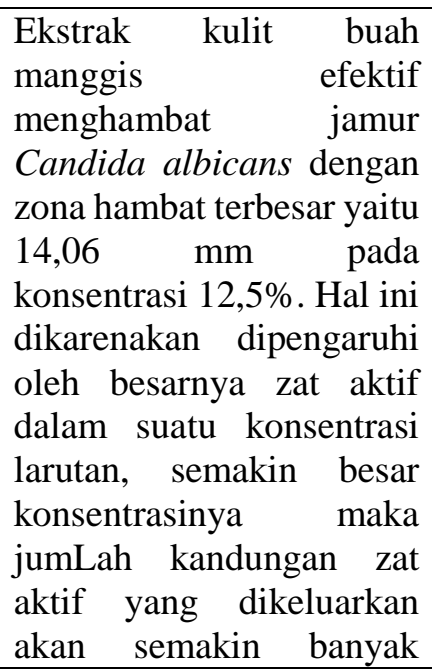 & $\begin{array}{l}\text { Chotimah } \\
\text { et al., } \\
2018 .\end{array}$ \\
\hline
\end{tabular}

\begin{tabular}{|c|c|c|}
\hline & 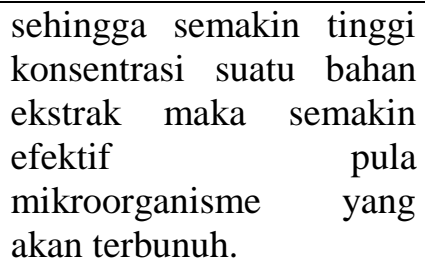 & \\
\hline 25. & $\begin{array}{lr}\text { Ekstrak kulit } & \text { apel } \\
\text { manalagi tidak } & \text { memiliki } \\
\text { daya hambat } & \text { terhadap } \\
\text { pertumbuhan } & \text { Candida } \\
\text { albicans bahkan } & \text { setelah } \\
\text { dilakukan partisi } & \text { untuk } \\
\text { memisahkan } & \text { ekstrak } \\
\text { berdasarkan ran sifat } & \text { kepolarannya. Namun, } \\
\text { ekstrak kulit apel manalagi } \\
\text { memiliki daya hambat } \\
\text { terhadap pertumbuhan } \\
\text { bakteri dan Hipotesis } \\
\text { ditolak, H0 diterima. }\end{array}$ & $\begin{array}{l}\text { Moersidi et } \\
\text { al., } 2015\end{array}$ \\
\hline 26. & $\begin{array}{l}\text { Menunjukkan bahwa } \\
\text { fraksi etil asetat memiliki } \\
\text { efektivitas antijamur } \\
\text { terbaik terhadap Candida } \\
\text { albicans dibandingkan } \\
\text { dengan fraksi metanol, n- } \\
\text { heksana, dan air pada } \\
\text { semua konsentrasi, } \\
\text { meskipun sedikit lebih } \\
\text { kecil dibandingkan } \\
\text { dengan kontrol } \\
\text { klorheksidin 2\%. KHM } \\
\text { fraksi etil asetat 15,63 mg } \\
\text { / mL, sedangkan MFC-nya } \\
31,25 \text { mg / mL. Analisis } \\
\text { MIC dengan satu sampel } \\
\text { uji t menunjukkan bahwa } \\
\text { fraksi etil asetat buah } \\
\text { merah berpengaruh nyata } \\
\text { terhadap Candida } \\
\text { albicans (P = 0,0053). }\end{array}$ & $\begin{array}{l}\text { Novianti et } \\
\text { al., } 2020\end{array}$ \\
\hline 27. & $\begin{array}{l}\text { Konsentrasi Minimum } \\
\text { penghambatan (MIC) dan } \\
\text { konsentrasi fungisida } \\
\text { minimum (MFC) matang } \\
\text { Cucumis melo ekstrak } \\
\text { buah metanol yang } 25 \times \\
10^{3} \text { dan } 5 \times 10^{4} \mathrm{mg} / \mathrm{mL} \text {, }\end{array}$ & $\begin{array}{l}\text { Azizi et } \\
a l ., 2014\end{array}$ \\
\hline
\end{tabular}


Jurnal Jeumpa, 7 (2) Juli-Desember 2020

\begin{tabular}{|c|c|c|}
\hline & $\begin{array}{l}\text { masing-masing. MIC dan } \\
\text { MFC belum menghasilkan } \\
\text { ekstrak buah metanol } \\
\text { adalah } 25 \times 10^{3} \text {. Untuk } \\
\text { buah matang ekstrak } \\
\text { etanol, MIC dan MFC } \\
\text { adalah } 25 \times 10^{3} \text { ug / mL } \\
\text { dan untuk dewasa C. melo } \\
\text { buah ekstrak etanol MIC } \\
\text { adalah } 25 \times 10^{3} \text { dan MFC } \\
\text { adalah } 5 \times 10^{4} \mu g \text { g mL. } \\
\text { Hasil kromatografi gas / } \\
\text { spektrometri massa (GC / } \\
\text { MS) menunjukkan bahwa } \\
\text { asam heksadekanoat } \\
\text { terdapat pada semua } \\
\text { ekstrak. } \\
\text { maksimum zona hambat } \\
\text { untuk ekstraksi metanol } \\
\text { dewasa dan belum dewasa } \\
\text { pada metode cakram } \\
\text { adalah } 12 \text { mm dan metode } \\
\text { dalam sumur masing- } \\
\text { masing adalah } 15 \text { dan } 17 \\
\text { mm. Dalam metode } \\
\text { cakram, untuk ekstrak } \\
\text { etanol dewasa dan dewasa } \\
\text { ukuran maksimum zona } \\
\text { hambat adalah } 35 \text { dan } 36 \\
\text { mm dan dalam metode } \\
\text { sumur, ukuran maksimum } \\
\text { zona hambat untuk ekstrak } \\
\text { etanol matang dan belum } \\
\text { matang adalah } 28 \text { dan } 15 \\
\text { mm, masing-masing. }\end{array}$ & \\
\hline 28. & $\begin{array}{l}\text { Ekstrak Morinda citrifolia } \\
\text { pada konsentrasi } 1000 \mu \mathrm{gg} / \\
\mathrm{ml} \text { efektif menghambat } \\
\text { pertumbuhan Candida } \\
\text { albicans }(16,6 \pm 0,3) \\
\text { dibandingkan dengan } \\
\text { kontrol positif - } \\
\text { amfoterisin B }(20,6 \pm 0,6) \text {. } \\
\text { Itu ditemukan sebagai } \\
\text { reaksi yang bergantung } \\
\text { pada dosis. }\end{array}$ & $\begin{array}{l}\text { Barang, } \\
2014\end{array}$ \\
\hline 29. & $\begin{array}{l}\text { Lektin } \\
\text { menunjukkan } \\
\text { aktivitas antibiotik yang } \\
\text { signifikan pada Candida }\end{array}$ & Silva, 2018 \\
\hline
\end{tabular}

\begin{tabular}{|c|c|c|}
\hline & $\begin{array}{l}\text { albicans pada konsentrasi } \\
\text { sub-penghambatan }(0,195 \\
\text { dan } 0,39 \mu \mathrm{g} / \mathrm{mL}) .\end{array}$ & \\
\hline 30. & $\begin{array}{l}\begin{array}{l}\text { CaIni dilakukan } \\
\text { sinergis } \\
\text { flukonazol } \\
\text { dengan }\end{array} \\
\text { menghambat semua ragi } \\
\text { yang diuji, mencapai } \\
\text { penghambatan } 100 \% \text { pada } \\
\text { Calni parapsilosis. } \\
\text { Konsentrasi penghambat } \\
\text { untuk pasangan sinergis } \\
\text { berkisar antara } 1,3 \text { sampai } \\
4,0 \text { kali di bawah Ca Thi } \\
\text { IC 50 dan dari nol sampai } \\
2,0 \text { kali di bawah IC } \\
\text { flukonazol } 50\end{array}$ & $\begin{array}{l}\text { Taveira et } \\
\text { al., } 2016\end{array}$ \\
\hline 31. & $\begin{array}{l}\text { Aktivitas antioksidan dari } \\
\text { ekstrak metanol buah } \\
\text { adalah } 82 \% \text {. Aktivitas } \\
\text { antiasetilkolinesterase } \\
\text { yang tinggi pada ekstrak } \\
\text { heksana mencapai } 71 \% \text {. } \\
\text { Ekstrak heksana buah } \\
\text { tidak menunjukkan } \\
\text { penghambatan untuk } \\
\text { Candida albicans }\end{array}$ & $\begin{array}{l}\text { Santana et } \\
\text { al., } 2019\end{array}$ \\
\hline 32. & $\begin{array}{l}\text { Menunjukkan bahwa } \\
\text { dengan meningkatkan } \\
\text { konsentrasi ekstrak } \\
\text { tumbuhan yang dihambat } \\
\text { oleh cendawan juga } \\
\text { mengalami peningkatan. } \\
\text { Selanjutnya konsentrasi } \\
\text { ekstrak Heracleum } \\
\text { persicum menghambat } \\
\text { pertumbuhan jamur ppm } \\
25 \text { sedangkan konsentrasi } \\
\text { ekstrak Peganum harmala } \\
\text { menghambat } \\
\text { pertumbuhan ppm } 50 .\end{array}$ & $\begin{array}{l}\text { Jahani et } \\
\text { al., } 2017\end{array}$ \\
\hline 33. & $\begin{array}{l}\text { Perbedaan yang signifikan } \\
\text { baik secara in vivo } \\
\text { maupun in vitroaktivitas } \\
\text { enzimatik diamati antara } \\
\text { strain L06 dan Candida } \\
\text { albicans. Analisis regresi }\end{array}$ & $\begin{array}{l}\text { Guerrero et } \\
a l ., 2014\end{array}$ \\
\hline
\end{tabular}


Jurnal Jeumpa, 7 (2) Juli-Desember 2020

\begin{tabular}{|c|c|c|}
\hline & 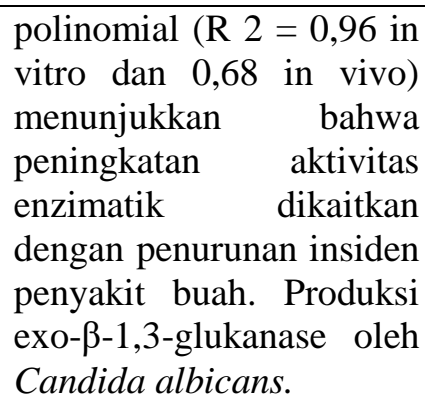 & \\
\hline 34. & $\begin{array}{l}\text { menunjukkan bahwa buah } \\
\text { delima,kulit dan bijinya } \\
\text { menggambarkan implikasi } \\
\text { terapeutik dalam } \\
\text { manajemen kesehatan } \\
\text { melalui penghambatan } \\
\text { efek radikal bebas dan } \\
\text { modulasi aktivitas enzim } \\
\text { yang terkait dengan } \\
\text { perkembangan dan } \\
\text { perkembangan penyakit. }\end{array}$ & $\begin{array}{l}\text { Rahmani et } \\
\text { al., } 2017\end{array}$ \\
\hline 35. & $\begin{array}{l}\text { Ekstrak A. vera pada } \\
\text { konsentrasi } 1000 \mu \mathrm{g} / \mathrm{ml} \\
\text { efektif menghambat } \\
\text { pertumbuhan Candida } \\
\text { albicans (14 } \mathrm{mm}) \\
\text { dibandingkan dengan } \\
\text { kontrol positif-amfoterisin } \\
\text { B (15 mm). Itu ditemukan } \\
\text { sebagai reaksi yang } \\
\text { bergantung pada dosis. }\end{array}$ & $\begin{array}{l}\text { Shireen et } \\
\text { al., } 2015\end{array}$ \\
\hline 36. & $\begin{array}{l}\text { Candida } \begin{array}{l}\text { albicans } \\
\text { tumbuh pada }\end{array} \text { mediak } \\
\text { dengan perlakuan } 100 \% \\
\text { minyak atsiri, tetapi } \\
\text { tumbuh pada media } \\
\text { dengan perlakuan minyak } \\
\text { atsiri 50\%. Tahap kedua } \\
\text { dilakukan pengenceran } \\
100 \%, 90 \%, 80 \%, 70 \% \text {, } \\
60 \% \text { dan } 50 \% \text {. } \\
\text { Pertumbuhan Candida } \\
\text { albicans ditemukan pada } \\
\text { media perlakuan 60\% dan } \\
\text { 50\%. Pada media agar- } \\
\text { agar,pertumbuhan terjadi } \\
\text { pada media kultur yang } \\
\text { diberi perlakuan } 70 \% \text {. }\end{array}$ & $\begin{array}{l}\text { Hernawan } \\
\text { et al., } 2015\end{array}$ \\
\hline
\end{tabular}

\begin{tabular}{|c|c|c|}
\hline 37. & $\begin{array}{lr}\text { SJA } & \text { menunjukkan } \\
\text { aktivitas } & \text { fungisida } \\
\text { terhadap berbagai jamur } \\
\text { dan jelas menghambat } \\
\text { pertumbuhan hifa jamur. }\end{array}$ & $\begin{array}{l}\text { Liu et al., } \\
2019\end{array}$ \\
\hline 38. & $\begin{array}{l}\text { Ekstrak yang ditambahkan } \\
\text { ke media setelah sterilisasi } \\
\text { menghambat } \\
\text { pertumbuhan sampel } \\
\text { jamur patogen lebih } \\
\text { banyak daripada ekstrak } \\
\text { yang ditambahkan ke } \\
\text { media sebelum sterilisasi. } \\
\text { Hal ini menunjukkan } \\
\text { bahwa bahan aktif yang } \\
\text { ada dalam ekstrak yang } \\
\text { memiliki efek antijamur } \\
\text { yang diamati terpengaruh } \\
\text { secara negatif dan } \\
\text { dinonaktifkan pada suhu } \\
121^{\circ} \mathrm{C} \text { selama } 15 \text { menit. }\end{array}$ & $\begin{array}{l}\text { Agi et al., } \\
2019\end{array}$ \\
\hline 39. & $\begin{array}{l}\text { MIC dan MFC dari citral } \\
\text { didirikan } 32 \mu \mathrm{g} / \mathrm{mL} \text {, } \\
\text { konsisten dengan aktivitas } \\
\text { fungisida. Strain klinis } \\
\text { resisten terhadap nistatin. } \\
\text { Citral menyebabkan } \\
\text { perubahan } \\
\text { mikromorfologis pada } \\
\text { strain. Pada kurva time- } \\
\text { kill, pertumbuhan strain } \\
\text { klinis mengalami } \\
\text { penurunan pertumbuhan } \\
\text { sebesar } 3 \text { log } 10 \text { unit } \\
\text { pembentuk koloni per } \\
\text { mililiter setelah terpapar } \\
\text { MIC dan MIC } 2 \text { dari } \\
\text { citral selama } 2 \text { jam. Citral } \\
\text { tidak memodulasi } \\
\text { resistensi strain yang } \\
\text { diteliti terhadap nistatin. }\end{array}$ & $\begin{array}{l}\text { Freire et } \\
a l ., 2017\end{array}$ \\
\hline 40. & $\begin{array}{l}\text { Konsentrasi Hambat } \\
\text { Minimum (KHM) dalam } \\
\text { menghambat } \\
\text { pertumbuhan Candida } \\
\text { albicans adalah pada } \\
\text { konsentrasi ekstrak } 0,4 \% \\
\text { dan waktu kontak yang }\end{array}$ & $\begin{array}{l}\text { Sukma et } \\
\text { al., } 2019\end{array}$ \\
\hline
\end{tabular}


Jurnal Jeumpa, 7 (2) Juli-Desember 2020

\begin{tabular}{|c|c|c|}
\hline & $\begin{array}{l}\text { efektif dalam menghambat } \\
\text { pertumbuhan Candida } \\
\text { albicans adalah pada } \\
\text { waktu kontak } 36 \mathrm{jam} \text {. }\end{array}$ & \\
\hline 41. & $\begin{array}{l}\text { Rataan hasil pengukuran } \\
\text { sirih merah=28,7, sirih } \\
\text { hutan=13,00, sirih } \\
\text { merah=15,46, K+=34,92, } \\
\text { dan K-=0. Hasil analisis } \\
\text { Ansira adalah Fhitung= } \\
49,72>\text { Ftabel=3,01 pada } \\
\text { taraf signifikan } \alpha=0,05 \\
(5 \%) \text { dengan DK V1=4 } \\
\text { dan V2= 16. Hasil Uji } \\
\text { Beda Jarak Duncan } \\
\text { menunjukkan bahwa } \\
\text { setiap perlakuan memberi } \\
\text { pengaruh yang sangat } \\
\text { nyata dalam menghambat } \\
\text { pertumbuhan jamur } \\
\text { Candida albicans. }\end{array}$ & $\begin{array}{l}\text { Zuraidah, } \\
2015 .\end{array}$ \\
\hline 42 & $\begin{array}{lr}\text { Hasil identifikasi fungi uji } \\
\text { Candida } \\
\text { berwarna krem serta } \\
\text { berbentuk oval. Perasan, } \\
\text { rebusan, dan seduhan daun } \\
\text { sirsak gunung } \\
\text { montana) } \\
\text { mempunyai } \\
\text { antifungi } & \text { tidak } \\
\text { pertumbuhan } & \text { terhadap } \\
\text { albicans. } & \text { Candida } \\
\end{array}$ & $\begin{array}{l}\text { Chotimah } \\
\text { et al., } \\
2018 .\end{array}$ \\
\hline
\end{tabular}

\section{PEMBAHASAN}

Candida albicans merupakan salah satu dari sekian banyak jenis jamur yang memiliki sifat diploid, dengan memiliki dua pasang dari 8 kromosom. Menurut Surain et al., 2019, jamur Candida albicans memiliki ukuran genom sekitar $16 \mathrm{Mb}$ (haploid). Secara morfologis Candida albicans adalah jamur dimorfik yang terutama terdapat dalam tiga bentuk yaitu sel ragi, pseudohyphae dan sel hifa sejati. Sel jamur berbentuk bulat telur dan mudah dipisahkan satu sama lain dengan pseudohyphae menyerupai sel ragi elipsoid yang memanjang dan tetap menempel antara satu dengan yang lain, di lokasi sekat yang terbatas dan biasanya tumbuh dalam pola bercabang. Sel hifa sejati panjang dan sangat terpolarisasi, dengan sisi paralel dan tidak ada penyempitan antar sel. Adanya beberapa faktor lingkungan pertumbuhan silinder dimulai pada permukaan blastospora membentuk tabung kuman.

Sel ragi dari jamur Candida albicans memiliki sifat berkembang biak dengan bantuan tunas dan menjalani morfogenesis. Maksudnya yaitu raginya akan berkecambah menghasilkan tabung kuman yang khas yang tumbuh sebagai pseudohyphae atau hifa sejati. Jamur Candida albicans disebut sebagai jamur patogen oportunistik karena jamur ini mempunyai kemampuan dengan cepat menginfeksi seseorang dengan kekebalan tubuh yang lemah atau dapat ditularkan secara seksual seperti orang yang terjangkit infeksi HIV, leukemia, diabetes, terapi obat, dan ibu hamil. Perkembangan jamur Candida albicans ditekan oleh mikrobiota normal tubuh manusia. Ketika mikrobiota normal 
Jurnal Jeumpa, 7 (2) Juli-Desember 2020

terganggu, kandida berkembang biak dan menghasilkan kandidiasis secara endogen.

Bentuk penyakit akibat Candida albicans disebut kandidiasis oral (moniliasis) (Prasidha, 2011) yaitu penyakit infeksi yang menyerang rongga mulut manusia tepatnya pada daerah-daerah lidah, orofaring, lipatan mukosa bukal dan mukosa bukal. Kandidiasis umunya dijumpai pada penderita HIV/AIDS, sehingga akibat permasalah ini telah banyak dilakukan penelitian dengan bahan utama berupa bahan alami yang telah tersedia di alam. Pemakaian bahan alami dalam jangka waktu yang panjang terbukti tidak memberikan efek yang berbahaya dibandingkan dengan penggunaan obatobatan. Berdasarkan hasil penelitian yang telah ada didapat bahwa senyawa-senyawa yang terkandung pada beberapa jenis bahan alami memiliki sifat antifungal yang mampu menghambat pertumbuhan jamur Candida albicans. Adapun beberapa senyawa metabolit sekunder yang bersifat antifungal yaitu seperti flavonoid, Tanin, Saponin, Alkaloid, Polifenol, Triterpenoid dan beberapa komponen aktif seperti alphamangostin.

Flavonoid merupakan jenis senyawa metabolit yang memiliki kemampuan kompleks untuk menghancurkan dinding sel bakteri. Tanin bekerjasama dengan protein trans-membran dan enzim-enzim pada permukaan membrane dapat merusak mikroba melalui ikatan hydrogen. Senyawa alkaloid mampu merusak struktir DNA bakteri sehingga dapat menghambat pertumbuhan mik roba. Adapun steroid dapat menghalangi tumbuhnya mikroba dengan merusak membran plasma sehingga menyebabkan bocornya sitoplasma ke luar sel yang selanjutnya menyebabkan kematian sel. Chotimah, (et al., 2018) melaporkan bahwa Alpha-mangostin sebagai kompenen aktif pada tumbuhan memiliki potensi untuk penanganan kandidiasis mulut dan zat alphamangostin lebih baik daya hambatnya dibandingkan clotrimazole dan nystatin. Mekanisme kerja zat alpha-mangostin yaitu menyerang struktur sel jamur khususnya komponen lipid utama dalam membran sehingga akhirna sel fungi tidak dapat lagi berfungsi.

\section{KESIMPULAN}

Senyawa metabolit yang terkandung pada bahan-bahan alami ialah seperti flavonoid, Tanin, Saponin, Alkaloid, Polifenol, Triterpenoid dan beberapa komponen aktif seperti alpha-mangostin mampu secara efektif mampu menghambat pertumbuhan jamur Candida albicans karena memiliki sifat antifungal. 
Jurnal Jeumpa, 7 (2) Juli-Desember 2020

\section{DAFTAR PUSTAKA}

Alfiah RR, Siti K, Masnur T. 2015. Efektifitas ekstrak methanol daun sembung rambat (Mikania micrantha Kunth) terhadap pertumbuhan jamur Candida albicans. Jurnal Protobiont 4: 52-57.

Agi VN, CA Azike. 2019. Aksi Anti Jamur Bawang Putih (Allium sativum) dan Jahe (Zingiber officinale) pada Beberapa Jamur Patogen. Jurnal Penelitian Biokimia Asia 4(4):1-6.

Azizi GI, Samaneh R, Fahimeh Y. 2014. Aktivitas Anti Jamur In vitro Cucumis melo pada Candida albicans. Zahedan Journal Of Resear Chin Medica Lsciences 17(7): 10-19.

Alzarea B, Sghaireen M, Taher L. 2015. Prevalence of oral candidiasis in diabetic patient at nothern of kingdom of saudi arabia. Jurnal Biol Sci 10: $10-4$.

Andriani D, Dwi S, Nafi'ah. 2017. Efek ekstrak Acanthus ilicifilus terhadap ekstrak antibodi Anticandida Albicans pada tikus Wistar terimunusupresi dengan oral Candidiasis. Jurnal Kedokteran Gigi 11: 35-42.

Burhannuddin, IW Karta, B Tresnanda, IGND Putra, Darmanda, Pradnyadhita, Gunawan, Ariawan. 2017. Daya hambat Virgin Coconut Oil terhadap pertumbuhan jamur Candida albicans. Jurnal Sains dan Teknologi 6: 209219.

Barani K, Sunayana M, D Prabu, Adil A, Preethi A, C Jeevika. 2014. Indian Journal Of Dental Research 25(2): 188-190.
Brook GF, Butel JS, Morse, SA. 2010. Mikrobiologi Kedokteran. JawetzMelnick and Andelberg Edisi 25, EGC, Jakarta. pp. 15-20.

Bommanavar S, Gugwad S, Malik N. 2017. Sakelar fenotipik: sistem transisi candida albicans putih-abu-abu yang membingungkan. Journal Lisan Maxillofac Pathol 21- 82.

Chakrabarti A, Sood P, Rudramurthy SM, Chen S, Kaur H, Capoor M, Chhina D, Rao R, Eshwara VK, Xess I, Kindo AJ, Umabala P, Savio J, Patel A, Ray U, Mohan S, Iyer R , Chander J, Arora A, Sardana R, Roy I, Appalaraju B, Sharma A, Shetty A, Khanna N, Marak R, Biswas S, Das S, Harish BN, Joshi S, Mendiratta D. 2015. Insiden, karakteristik dan hasil ICU Candidemia yang didapat di India. Journal perawatan Intensif Med 41: 285-95.

Chotimah C, Diah W, Nurasisa L. 2018. Uji daya hambat eksrak kulit buah manggis (Garcinia mangostana L.) terhadap pertumbuhan Candida albicans secara in vitro (Studi Eksperimen Dilaboratorium Mikrobiologi Farmasi Universitas Muslim Indonesia 2017). Jurnal Assyifaa 10: 110-119.

Deza AI. 2010. Kemampuan tanaman obat menghambat pertumbuhan Candida albicans penyebab sariawan secara invitro. Skripsi. UNP, Padang.

Fatimah AI. 2016. Pengaruh ekstrak flavonoid rendah nikotin limbah daun tembakau terhadap kasturi (Nicotiana tabacum L.) terhadap pertumbuhan mikroba rongga mulut. Skripsi. Fakultas Kedokteran Gigi, Universitas Jember. 
Jurnal Jeumpa, 7 (2) Juli-Desember 2020

Felita, Lelyana S, Winata T. 2020. Efek seduhan teh hitam terhadap pertumbuhan Candida albicans. Jurnal SONDE (Sound of Dentistry) 2: 24-31.

Freire PCJ, José Klidenberg DOJ, Daniele DFS, Janiere PDS, Felipe GSQ, Edeltrudes LOD. 2017. Aktivitas Antijamur Minyak Atsiri terhadap Strain Candida albicans yang Diisolasi dari Pengguna Prostesis Gigi.

Gharmita YS, Lelyana S, Sugiaman VK. 2019. Kadar hambat minuman (KHM) dan kadar bunuh minuman (KBM) ekstrak etanol daun ketepeng cina (Cassia alata L. ) terhadap pertumbuhan Candida albicans. Jurnal SONDE (Sound of Dentistry) 4: 1-15.

Guerrero V, Cesar G, David B, Damaris O. 2014. Pengendalian lengkap Penicillium expansum pada buah apel menggunakan kombinasi ragi antagonis Candida oleophila. Jurnal Penelitian Pertanian Chili.

Harianto KI, Pieter LS, Christy M. 2017. Uji daya hambat perasan rimpang kunyit (Curcuma longa L.) terhadap pertumbuhan Candida albicans. Jurnal Ilmiah Farmasi. 6: 1-6.

Hernawan I, Radithia D, Hadi P, Ernawati D. 2015. Efek penghambatan jamur dari minyak esensial kulit jeruk limon pada Candida albicans. Jurnal Gigi 48(2):84.

Hidayatullah M. 2012. Uji daya antifungi minyak atsiri bawang merah (Allium ascalonicum L.) terhadap Candida albicans ATCC 10231 secara in vitro. Naskah Publikasi, Fakultas Kedokteran, Muhamadiyah Surakarta.
Irianto K. (2014). Bakteriologi medis, mikrobiologi medis dan virology medis. Alfabeta, Bandung. pp. 365.

Jahani S, Saphora B, Zahra S, Maryam SA, Fahimeh M, Gelareh SB. 2017. Pengaruh Anti Jamur Ekstrak Tanaman Terhadap Candida albicans. Internasional Journal of Infection $4(2)$.

Komala O, Ike Y, Rita P. 2012. Uji efektivitas etanol daun lidah mertua (Sansevieria trifasciata Prain) terhadap khamir Candida albicans. Jurnal Fitokarmaka 2: 146-152.

Kim TH, Kweon OJ, Kim HR, Lee MK. 2016. Identifikasi spesies Candida yang tidak umum menggunakan sistem identifikasi komersial. Juornal Microbiol Biotechnol 26(22):6-13.

Khotimah S. 2018. Aktivitas Antifungi Perasan, Rebusan, dan Seduhan Daun Sirsak Gunung (Annona montana) terhadap Pertumbuhan Candida albicans. Karya Tulis Ilmiah Akademi Farmasi Putra Indonesia Malang.

Kalista, KF. 2017. Karakteristik Klinis dan Prevalensi Pasien Kandidiasis Invasif di Rumah Sakit Cipto Mangunkusumo. Jurnal Penyakit Dalam 34: 104-115.

Liu W, Baozheng S, Manman Y, Zhang, Xiuxiu Z, Tingsong P, Shengzheng W. 2019. Aktivitas Anti Jamur Ekstrak Kasar dari Rimpang dan Akar Smilacina japonica A. Gray. Jurnal Ilmiah Microbiol Biotechnol.

Maimunah E. 2018. Uji efektivitas air buah jeruk nipis (Citrus aurantifolia) dalam menghambat Candida albicans (Studi di STIKES ICMe Jombang). Karya 
Jurnal Jeumpa, 7 (2) Juli-Desember 2020

Tulis Ilmiah. Sekolah Tinggi Ilmu Kesehaan, Insan Cendikia Medika Jombang.

Masloman PG, Pangemanan, Anindita. 2016. Uji daya hambat ekstrak daun sirsak (Annona murcata L.) terhadap pertumbuhan jamur Candida albicans. Jurnal Ilmiah Farmasi 5: 61-68.

Moersidi, Maghfirah, Nurul, siti. 2015. Daya hambat minimal eksrak kulit apel manalagi terhadap pertumbuhan Candida albicans. Skripsi. Fakultas Kedokteran Gigi, Universitas Hasanuddin.

Nuryani S, Jhunnison. 2016. Daya antifungi infusa daun kenikir (Cosmos caudatus K.) terhadap pertumbuhan jamur Candida albicans secara in vitro. Jurnal Teknologi Laboratorium 5(1): 5-11.

Novianti MPV, Lisda D, Aprillia A, Yuri M. 2020. Efektivitas buah merah ( Pandanus conoideus Lam.) Terhadap Candida albicans (ATCC 10231) di bidang prostodontik: Studi eksperimental. Journal of internasional Oral Health 12(3): 260269.

Pokote CF. 2018. Daya hambat madu hutan Sulawesi tengah terhadap bakteri Staphylococcus aureus dan Candida albicans. Manuscript. Fakultas Ilmu Keperawatan Dan Kesehatan, Universitas Muhamadiyah Semarang.

Pollyanna MDS, Maiara CDM, Francis Soares G, Danielle DST, Ana PSDO, Gabriela SVDM, Maira GDRP, Moacyr JBDMR, Luana CBBC, Alexandre JM, Regina CBQDF, Patrícia MGDP, Thiago HN. 2018. PgTeL, lektin yang ditemukan di Punica granatum jus, adalah agen anti jamur melawan Candida albicans dan Candida krusei. Journal Chemical Engineering Transactions 108: 391-400.

Rahmi A, Erfan R, Leka L. 2016. Potensi ekstrak rimpang kencur (Kaempferia galangal L.) menghambat pertumbuhan Candida albicans. Jurnal Ilmiah Farmasi 2: 70-76.

Rahman FE. 2020. Efektifitas ekstrak daun dewa (Gynura pseudochina (Lour.) DC) terhadap pertumbuhan Candida albicans pada plat dasar gigi tiruan resin akrilik. Jurnal Majalah Ilmiah Sultan Agung 48: 32-45.

Rahmani HA, Mohamed AA, Saleh AA. 2017. Konstituen Aktif Buah Delima (Punica granatum) sebagai Calon Potensial dalam Pengelolaan Kesehatan Melalui Modulasi Kegiatan Biologis. Jurnal Farmakognosi 9(5): 689-695.

Rahmah, N., dan KN,A.R. 2010. Uji fungistatik ekstrak daun sirih (Piper betle) terhadap Candida albicans. Jurnal Bioscientiae 7: 17-24.

Rezeki S, Santi C, Aulia I. 2017. Pengaruh eksrak daun sirih merah (Piper crocatum) terhadap pertumbuhan Candida albicans. Jurnal Syiah Kuala 2: 52-62.

Sari M, Cicik suryani. 2014. Pengaruh ekstrak daun belimbing wuluh (Averhoa bilimbil L.) dalam menghambat pertumbuhan jamur Candida albicans secara in vitro. Prosiding. Seminar Nasional Biologi dan 
Pembelajaran. Medan, Agustus 23. pp. 325-332.

Shireen F , Sunayana M, D Prabu. 2015. Aktivitas antijamur lidah buaya: Studi in vitro. Journal of Research In Dental Science 6(2):92-95.

Sukma RP, Rahmat M, Duminar A, Rahayu IG. 2019. Uji efektivitas ekstrak serai dapur (Cymbopogon citratus (DC.) stapf) terhadap pertumbuhan Candida albicans metode makrodilusi. Jurnal Riset Kesehatan 11(2).

Sopiah S, Utmi A, Busman. 2017. Aktivitas antijamur ekstrak buah pinang tua (Areca catechu L.) terhadap jamur Candida albicans pada pasien kandidiasis rongga mulut. Jurnal BDent 4: 126-132.

Sari M. 2014. Pengaruh perendaman bahan basis gigi tiruan valplast dalam larutan ekstrak bawang putih terhadap pertumbuhan Candida albicans. Skripsi. Fakultas Kedokteran Gigi, Universitas Hasanuddin Makassar.

Sulityowati I. 2012. Uji aktivitas ekstrak etanol daun lidah buaya (Aloe vera) terhadap bakteri Staphylococcus aureus dan jamur Candida albicans. Skripsi. Fakultas Ilmu Kesehatan. Universitas Negeri Alauddin Makassar.

Santana M, Karla MS, Bruna OVB, Lucianne CC, Pollyana GRDM, Ana CT, Jacqueline A, De MF, Antonio A. 2019. Ekstrak Bioaktif Capsicum Chinense di Amazon Utara. Journal chemical engineering transactions 65: 433-438.
Sukmawati, I Nengah K, Gamar B, Non S. 2017. Efektivitas antimikroba eksrak daun jarak pagar (Jatropha curcas L) terhadap pertumbuhan jamur Candida albicans dan pemanfaatannya sebagai media pembelajaran. Jurnal e-JIP BIOL 5: 1-18.

Sudrajat, H dan Azar, F.2011.Uji aktivitas antifungi minyak atsiri rimpang temulawak (Curcuma xanthorriza Roxb.) secara in vitro terhadap Candida albicans. Publikasi Ilmiah, Unwahas.

Suryaningsih, A., Siti chumaeroh dan B. Benyamin. 2015. Uji efektivitas ekstrak anggur merah (Vitis vinivera) terhadap pertumbuhan Candida albicans secara inVitro. Jurnal Ilmiah Farmasi 6: 45-48.

Surain, Perveen; Neeraj K. Aggarwal. 2019. Candida, sebuah patogen manusia dan jenis utama Candidiasis. Journal Internasional ilmu dan penelitian farmasi.

Tivani N, Wilda A. 2020. Uji efektifitas antifungi perasan daun turi (Sesbania grandiflora (L.) Pers.) terhadap jamur Candida albicans. Jurnal Farmasi Indonesia 17: 3541.

Taveira BG, André OC ,Rosana R ,Fernanda GT, Maura DC, Valdirene MG. 2016. Peptida mirip thionin dari buah Capsicum annuum: mekanisme kerja dan sinergisme dengan flukonazol terhadap spesies Candida. Journal Microbiology BMC 16(12): 1-34.

Wijayanti HMD, Made AH, Ni Kade FRP. 2020. Ekstrak daun kedondong 
Jurnal Jeumpa, 7 (2) Juli-Desember 2020

hutan (Spondias pinnata) menghambat pertumbuhan Candida albicans dari penderita oral thrush secara in vitro. Jurnal Bali Dental 4: 8-12.

Wijaya C. 2017. Perbedaan efek anti fungi minyak atsiri kayu manis (Cinnamum burmanii), lengkuas (Alpinia galangal 1.) Dan kombinasinya terhadap Candida albicans secara in vitro. Universitas Sebelas Maret.
Yusri A, Muda S, Rasmaliah. 2012. Karakteristik penderita AIDS dan infeksi oportunistik di rumah sakit umum pusat Adam Malik Medan tahun 2012. Jurnal Ilmiah Farmasi 4: 62-65.

Zuraidah. 2015. Pengujian ekstrak daun sirih (piper sp.) yang digunakan oleh para wanita di gampong dayah bubue, pidie dalam mengatasi kandidiasis akibat cendawan Candida albicans. International Journal of Child and Gender Studies 1 (2): 109-118. 